\title{
A TOLERÂNCIA E O DIREITO: POSSIBILIDADES, PROJEÇÕES E LIMITES NA PERSPECTIVA JURISPRUDENCIALISTA
}

\section{Ian Pimentel Gameiro ${ }^{1}$}

\section{Resumo}

$\mathrm{O}$ artigo tem como objetivo responder a questão de saber qual o sentido que a relação entre a tolerância e o direito comporta ou pode comportar no mundo prático do homem. Nosso pressuposto teórico é o de que, por um lado, e sendo a tolerância uma categoria normativamente dependente, tanto poderá o direito aparecer-lhe como apenas um recurso normativo dentre vários possíveis, quanto, por outro, poderá a própria tolerância vir a ser um recurso normativo, enquanto princípio ou critério, do direito. Para responder esta questão, dividimos o artigo em três seções. Na primeira, identificamos, mediante duas aproximações etimológicas, os significados que a categoria tolerância tem assumido no mundo cultural do Homem. Na segunda, buscamos construir um conceito analítico para o nosso objeto e as condições necessárias para a sua prática. Na terceira seção, por fim, buscamos verificar como se estrutura a relação entre direito e tolerância e que efeitos normativos possíveis decorrem dessa relação.

Palavras-chave: Tolerância; Direito; Princípio; Critério; Tolerância Jurídica.

\section{INTRODUÇÃO}

Uma conjunção coordenativa aditiva ("e") interpusemos entre $A$ Tolerância e $O$ Direito para suscitar a reflexão acerca de uma relação temática que, se na nossa circunstância presente e no nosso contexto civilizacional

\footnotetext{
1 Doutorando em Ciências Jurídico-Filosóficas pela Faculdade de Direito da Universidade de Coimbra - Portugal (2015). Professor de Direito Constitucional na Graduação e Pós-Graduação da Universidade da Amazônia - UNAMA. E-mail: pimentel.ian.ip@gmail.com
} 
mostra-se cada vez mais decisiva e crucialmente importante, isto por um lado; já por outro, se nos revela apenas como uma relação eventual, com o sentido de ser essa uma relação somente de possibilidades, projeçóes e limites.

Explico. Entendemo-la uma relação cada vez mais crucial porque, ao fim e ao cabo, reclama do homem uma reflexão-limite acerca do seu projeto de si próprio e do seu encontro intersubjetivo com os demais no mundo prático - ou das exigências que uma tal reflexão projeta nesse encontro - num tempo em que, afinal, vemo-nos cada vez mais vinculados quanto mais evidentes são as nossas diferenças. Compreendemos ser, entretanto, uma relação de verificação apenas eventual porquanto constituindo a tolerância uma categoria externa ao direito - e mais adiante veremos os motivos - nem por isso se deixam de seletivamente conectar e de ser aquela, em certas circunstâncias, por este assimilada.

Ora, se é verdade que a unicidade do mundo determina-nos um modo de ser-com-outros ${ }^{1}$ - habitando pluralmente o mundo, vemo-nos obrigados a partilhá-lo e a comungá-lo seja mediante uma conjugação de esforços em vista de objetivos comuns, seja mediante uma interposição mútua relativamente às pretensões uns dos outros (NEVES, 2008) - então, e neste nosso tempo de uma quase agonística geral, pensar a relação da categoria tolerância com o mundo prático do direito não só é sempre atual quanto é cada vez mais urgente?

E é porque se mostra assim - nessa sua relevância, urgência e eventualidade -, que importa perguntar: como se pode estruturar a relação entre a tolerância e o direito no mundo prático do Homem? Tem sentido falarse da tolerância como princípio jurídico autônomo? Em que medida pode essa relação ser configurada de modo a, assumindo-se a ideia de tolerância no direito, projetar efeitos materialmente jurídicos? Quais são os limites, se os houver, da própria categoria tolerância e desta projeção (FORST, 2016)? Eis como consideramos nosso problema de reflexão condutor e algumas das suas questões correlatas.

Com efeito, embora a categoria tolerância, tal como apontara David Heyd (1996), só com o liberalismo tenha adquirido um estatuto de valor social fundamental, a sua mobilização nos diversos regimes de discurso sejam eles o filosófico, o jurídico, o moral ou o religioso - em muito supera este período dos últimos três séculos em que a mundividência liberal acha-se compreendida.

Ainda assim, contudo, permanece bastante controverso saber quais são, de fato, os significados possíveis para o significante 'tolerâncià. Daí que, e longe de pretender uma solução para o problema, tenhamos este como o primeiro ponto do nosso percurso em busca de uma resposta para a questão principal.

Mas esta primeira aproximação, entretanto, não se restringe só a este aspecto. Lança-nos também para a questão de saber o que de fato a tolerância constitui e quais são os seus elementos constitutivos. É dizer: o que distingue a tolerância, em termos analíticos, do reconhecimento, da aceitação ou da indiferença, e quais são as condições que devem existir para ser possível a sua prática?

Percurso este, entretanto, que não esgota e antes suscita ainda uma terceira e decisiva interrogação, sendo 
precisamente esta: se a tolerância constitui uma categoria normativa, então o que ela impõe juridicamente aos indivíduos e quando impõe? Isto é, o que significa ser juridicamente tolerante, e quando devo sê-lo? Existe um dever de ser tolerante e, em caso positivo, que tipo de comportamentos ou atitudes devo adotar, ou não adotar, para conformar-me a ele?

Todas essas as questões acerca das quais, nessa convocação da relação entre $a$ tolerância e $o$ direito, pretendemos muito modestamente refletir e para as quais oferecer, na economia de uma reflexão, algumas respostas.

\section{CONSTRUINDO O OBJETO: DUAS APROXIMAÇÕES ETIMOLÓGICAS}

A primeira frase com que Andrew Fiala (2005) inicia o seu Tolerance And The Ethical Life é esta: "A tolerância, enquanto princípio político, tem desfrutado de enorme sucesso no Ocidente moderno" (tradução nossa)3. Catriona Mckinnon e Dario Castiglione (2003a) igualmente iniciam Toleration, Neutrality and Democracy reconhecendo que "a tolerância é uma das questões mais importantes para a definição de uma teoria moral e política com aplicação às modernas sociedades globalizadas" (tradução nossa) ${ }^{4}$, ideia que da mesma forma retomam na sua introdução à The Culture of Toleration in Diverse Societies (MCKINNON; CASTIGLIONE, 2003b). Também Raphael Cohen-Almagor (2006) principia o seu The Scope of Tolerance considerando que "O conceito de tolerância e seu escopo legítimo situam-se no centro da [sua] análise" (tradução nossa $)^{5}$. E, desta forma, ou deste ponto de partida, seguem inúmeros outros autores e inúmeras outras propostas.

Com efeito, o modo como o problema da tolerância tem sido perspectivado e respondido pela literatura especializada é - bem o sabemos - bastante diverso e divergente. A despeito disso, contudo, um ponto comum permite conjugar essas e todas as propostas existentes: o reconhecimento de que a tolerância constitui uma categoria normativa de importância decisiva no nosso contexto espaço-temporal. Isto é, embora por razões bem distintas e cujas referências deixaremos de mencionar, todos parecem concordar que a tolerância constitui um pressuposto fundamental para o funcionamento das ocidentais sociedades pluralistas e democráticas.

Mas ao que exatamente todos estes autores se referem nas suas distintas propostas quando empregam o significante 'tolerâncià? Quais são os seus significados possíveis? Em quais contextos podemos utilizar esta palavra e para quais finalidades?

Sem embargo, quotidianamente somos todos nós confrontados com situações nas quais, por variadas razões e por diferentes fundamentos, sentimo-nos impelidos a autorrestringir nosso comportamento em vista de manter, digamos assim, uma relativa "paz" ou "harmonia social", ainda que essa paz seja apenas um meio para atingir outras finalidades. 
Essa tentativa de manter alguma harmonia social é o que nos leva, por exemplo, a aguentar o incômodo barulho da vizinhança em horários inapropriados; a contemporizar a queixa de um colega de trabalho acerca de outro; a consentir com o morador de rua a pedir algum dinheiro para sobreviver; ou, ainda, a aturar os comportamentos desrespeitosos dos filhos pequenos dos nossos amigos.

Por trás de todas essas circunstâncias de tolerância, como dirá Garzon Valdéz (2016), e deste comportamento que costumamos adotar, está a ideia, para uns mais clara, para outros mais obscura, de capacidade de 'resistir', capacidade de 'suportar' ou de 'sofrer', 'persistir', 'admitir'... Isto é, pensamos que em situações e contextos tais, estamos de fato a por à prova essa nossa capacidade de resistir a uma reação mais imediata, e é exatamente isto o que nos vem à cabeça quando também exigimos ou entendemos que alguém deva tolerar algo ou outrem.

Mas, se é verdade que o verbo tolerar por um lado remete para este tipo de comportamento como que autorrestringido, já não se pode dizer, por outro, que esteja historicamente limitado a essas significações e usos atualmente mais estabilizados. Ana Margarida Gaudêncio, numa reconstrução etimológica do vocábulo, aponta que remotamente o verbo tolerar também remeteu para as ideias de "levantar, erguer, elevar, levar, embarcar, criar, educar, encorajar, reconfortar, mas também destruir, suprimir, fazer desaparecer, abolir..., "....] sustentar, manter, alimentar, persistir a, combater", e o substantivo tolerância para as de "[...] constância em suportar, paciência" (GAUDÊNCIO, 2012, pp. 37-38)...

[...] acção de tolerar, isto é, de admitir sem reacção defensiva, atitude que consiste em deixar aos outros a liberdade de exprimirem opiniōes divergentes e de viverem em conformidade com tais opiniões, condescendência, indulgência, aptidão do organismo para suportar certos medicamentos, permissão, paciência (GAUDÊNCIO, 2012, pp. 38-39).

Com efeito, este tipo de recuperação de sentidos históricos ajuda-nos a perceber uma distinção importante relativamente ao modo como o vocábulo tolerância tem sido empregado em termos semânticos - e neste ponto nos parece lograda a intenção e a realização de Ana Margarida Gaudêncio.

Sem excluir usos e significações outras, podemos perceber que a palavra tolerância costuma ser empregada ora para designar a prática do verbo tolerar - e refere nessa sua explicitação ao ato, ação ou exercício intersubjetivo da tolerância, da não interferência -, ora para designar o substantivo 'tolerância', no que remete, com esta designação, para uma capacidade de resistir, de aguentar, de suportar.

E isto quer dizer o quê? Bem, enquanto a prática do verbo tolerar somente pode, semanticamente, significar o ato ou o exercício da tolerância qualquer que seja o fundamento normativo (ético, moral, jurídico, religioso...) invocado para sustentar esta ação, o substantivo tolerância pode vir a significar coisas diversas. Isto é, tanto podemos utilizá-lo para significar uma virtude da tolerância, quanto para nos referirmos a um valor de tolerância, ou, ainda, e sem excluir outros empregos possíveis, para descrever o atributo ou característica da 
tolerância que alguém ou alguma instituição manifesta (FIALA, 2005).

Ora, é precisamente esta distinção que tem alimentado um dos mais profundos debates a respeito do tema no âmbito do contexto anglo-saxão. Isto porque, e diferentemente do uso indistinto que na língua portuguesa se faz do vocábulo, no contexto da língua inglesa a literatura não só costuma atribuir para a prática do verbo tolerar e para o substantivo tolerância dois termos distintos e, em alguns casos, suscitar até um terceiro (KING, 1998) $)^{6}$ termo para referir a uma suposta "doutrina" da tolerância, como distribui essas significações de forma bastante dissonante (NICHOLSON, 1985)7.

Há, em primeiro lugar, o vocábulo toleration, que emprega-se no sentir de Peter Nicholson para designar "precisamente o ato de ser tolerante (ou a disposição para ser tolerante)" (tradução nossa) ${ }^{8}$, isto é, consiste na prática do verbo tolerate. Há, posteriormente, e em segundo lugar, o vocábulo tolerance, que, para Andrew Fiala, "é geralmente utilizado como um termo para descrever a virtude, característica ou tendência de se engajar em atos de tolerância" (tradução nossa) ${ }^{9}$; constitui, por assim dizer, o termo de designação do substantivo. E há, por fim, em terceiro lugar, o já em desuso vocábulo tolerantionism, que, para Preston King (1998), utilizava-se para designar as doutrinas religiosas da tolerância que prosperaram, sobretudo, durante e após a Grande Reforma.

Ainda no âmbito desta tripla distinção, subsiste na língua inglesa uma especificação de uso quanto aos vocábulos tolerance e toleration, com o primeiro a designar geralmente uma capacidade de suportar "algum desconforto físico, como a dor", e o segundo a designar uma capacidade de suportar "algum desconforto intelectual, como uma doutrina concorrente" (KING, 1998, p. 12).

Com efeito, e pretendendo uma superação radical desta dicotomia, Preston King (1998) propõe e avança no sentido de considerar a toleration uma negação de todas as formas de intolerância, e a tolerance apenas uma negação mínima e específica de intolerância, com intolerance a significar uma objeção a um objeto combinada com uma reação negativa contra ele.

Com o que, num primeiro momento do seu pensamento, a "toleração" incluirá a tolerância assim como outras formas de negação da intolerância, tais como o sacrificio ou o favoritismo, e, num momento posterior, incluirá também a tolerância fraca, a tolerância forte, a conveniência positiva, a conveniência negativa, a indiferença, o sacrificio forte, o sacrificio fraco o favoritismo (KING, 1998, pp. xii-xiii).

De fato, e tendo-se em conta que na língua portuguesa inexiste um termo específico capaz de designar o ato ou a prática de tolerar, sendo, portanto, por nós totalmente inaplicável estas distinções mais detalhadas que se operam no contexto anglo-saxão, limitaremo-nos a considerar e a empregar o vocábulo tolerância para designar o substantivo (virtude, valor, característica, etc.) e, tal como propõe Ana Margarida Gaudêncio (2012, p. 43), "a respectiva prática - «toleration»-pela expressão prática de tolerância”. 


\section{ELEMENTOS CONSTITUTIVOS E CONDIÇÕES DA CATEGORIA TOLERANCIA}

Ora, estas aproximações etimológicas e as consequências práticas delas retiradas projetam-nos já para o tema do conceito analítico de tolerância, e nos deixam em condições de perceber esta distinção importante entre o que são condições de possibilidade para uma prática da tolerância e o que são elementos constitutivos da categoria tolerância.

De fato, esta não é uma distinção comumente encontrada na literatura e a maior parte da doutrina considera condiçôes de possibilidade e elementos constitutivos como sinônimos, ou um ou outro globalmente conforme cada proposta (RUIZ, 1985). Para nós, entretanto, parece-nos mesmo que deva existir aqui alguma diferenciação.

A razão é simples, mas suficiente para sustentar nosso ponto de vista: uma coisa são as condiçôes contextuais que devem pressupostamente existir para termos a possibilidade de tolerar algo e/ou alguém; outra, muito distinta, são os elementos constitutivos que formam o conceito analítico de tolerância e que o distinguem, em razão desses elementos, de outros objetos correlatos no mundo prático-cultural - tolerância não é sinônimo de reconhecimento, como também não é de indiferença ou de mera resignação.

Isto não significa, entretanto, que algumas dessas condições de possibilidade para a prática da tolerância, bem como alguns de seus elementos constitutivos, não possam constituir também elementos constitutivos e condiçôes de possibilidade da prática do reconhecimento, da indiferença, da neutralidade, etc. Não. Mas, em verdade, na conjugação total e no sentido singular de alguns deles é que repousa a nota distintiva da tolerância.

Comecemos pelos elementos, todos eles, tais como as condições de possibilidade da prática, necessários, cumulativos e indispensáveis.

Em primeiro lugar, a tolerância estabelece uma (I) relação entre dois sujeitos - o tolerante e o tolerado. Esses sujeitos tanto podem ser pessoas físicas e singulares, tal como eu e o meu vizinho; quanto podem ser duas pessoas coletivas ou grupos sociais, tal como o grupo dos heterossexuais e o dos homossexuais; ou, ainda, uma pessoa singular e uma pessoa coletiva/grupo social, tal como o cidadão individual e o Estado (GAUDÊNCIO, 2012).

Essa relação tem uma marca característica, e bem a acentua Ana Margarida Gaudêncio: é como que uma não-relação, uma "relação exactamente marcada pela ausência... de relação" (GAUDÊNCIO, 2012, p. 338). Isto é, eu tolero o volume elevado produzido pelo reprodutor de músicas do meu vizinho e, ao fazê-lo, deixo de estabelecer com ele qualquer tipo de contato ou relação; ponho-me de costas.

Com efeito, esta relação de ausências tanto pode estar estruturada verticalmente, numa supra-infraordenação das posições de tolerante e de tolerado, quanto pode estar estruturada horizontalmente, e assim numa 
equidistância nivelada entre tolerante e tolerado. $O$ primeiro tipo de estruturação da relação de tolerância costuma-se verificar, por exemplo, entre o Estado e os cidadãos, entre uma Igreja e seus fiéis, ou entre um colonizador e um colonizado. O segundo tipo de estrutura, por sua vez, costuma-se verificar na relação de tolerância que os cidadãos estabelecem entre si, ou que os grupos sociais mantêm uns com os outros (GAUDÊNCIO, 2012).

Em segundo lugar, a tolerância pressupõe um (II) objeto conhecido - precisamente aquilo que é ou deve ser tolerado (RUIZ, 1985). Este objeto não possui uma forma específica ou é de tipo pré-determinado. Assim, pode constituir, por exemplo, um conjunto de crenças, convicções, práticas ou comportamentos de todas as naturezas.

É indispensável, contudo, e bem o ressalta Andrew Cohen (2004), que o sujeito ativo tenha total conhecimento da existência concreta do objeto a ser tolerado. O motivo, para tanto, é evidente: eu não posso ser tolerante com o consumo infantil de tabaco se eu desconheço a existência de crianças que o consomem, como não posso ser tolerante com a prática da mutilação genital feminina se eu desconheço a existência desta prática degradante no seio de qualquer comunidade. A não reação que constitui o elemento central do conceito não pode estar fundada numa ignorância ou num desconhecimento total do objeto.

Depois, e qualquer que seja a forma assumida, deve ele ser considerado (III) axiologicamente refutável por aquele que o tolera (GALEOTTI, 2004) - é dizer, inexistindo este elemento, já não mais teremos tolerância senão, eventualmente e conforme o caso, aceitação ou indiferença.

Ora, isto significa que deve haver aqui uma rejeição do objeto pela parte do sujeito ativo da relação, mas não uma qualquer refutação circunstancial ou de pura conveniência, senão um juízo negativo fundamentado em uma convicção essencial do sujeito tolerante - o que Rainer Forst $(2013)^{10}$ chamará, por um lado e sob influência de King $(1998)^{11}$, de componente de objeção, e Ana Margarida Gaudêncio (2012), por outro, de divergência essencial de base.

A divergência de base, traduzindo não um qualquer desacordo de circunstância mas uma discordância essencial, por um lado, havendo de ser, por outro, materialmente fundamentada, implica estabelecer desde logo uma distinção fulcral entre aquele e esta: na tolerância, o desacordo toca pontos fulcrais das convicções axiológicas dos sujeitos, havendo, portanto, razões de fundo que determinam a discordância face ao comportamento tolerado (GAUDÊNCIO, 2012, p. 374).

Esta objeção axiologicamente fundada - distinguindo-se assim de um mero 'não gostar' - não necessita de ser apenas moral; "as razões de objeção de práticas particulares podem ser de vários tipos diferentes e as razões morais representam apenas uma categoria possível" (tradução nossa) 12 (FORST, 2013, p. 19).

É preciso, entretanto, que este fundamento axiológico invocado para a rejeição do objeto da relação seja legítimo, ou seja, suscetível de ser publicamente legitimado pelo sujeito tolerante, "o que exclui de imediato certas 
práticas que, material-axiologicamente injustificadas, não conferem a qualidade de tolerante a quem abdique de as praticar" (GAUDÊNCIO, 2012, p. 375).

Com efeito, para haver tolerância numa relação entre dois sujeitos, é necessário que um deles - o sujeito ativo - (III) intencionalmente abstenha-se de atuar contra o outro - o sujeito passivo - pela mediação do objeto (WALDRON, 2003). Como bem aponta Andrew Cohen (2004), este é o coração da tolerância: a não reação intencional contra o outro.

Isto significa dizer o seguinte. Primeiramente, o sujeito tolerante necessita estar convencido da não interferência. Isto é, não pode deixar de reagir por desconhecer a existência do objeto, tal como sustentamos linhas atrás, como não pode deixar de reagir porque tal comportamento lhe fora imposto exteriormente. Ele precisa ter a oportunidade de escolher se comportar dessa forma e, sendo o caso, por ela optar intencionalmente (COHEN, 2004).

Ato contínuo, é indispensável que o sujeito tolerante opte por não reagir intencionalmente contra $o$ outro. Isto significa, de um lado, que já não teremos um sujeito tolerante se a atuação for a favor do outro - caso do reconhecimento -, como também já não teremos um sujeito intolerante se for por ele ignorada ou desconhecida, de outro lado, a circunstância de estar atuando contra o sujeito passivo. É absolutamente necessário que o sujeito ativo optepor não atuar contra o outro sabendo que assim o faz.

Essa abstenção intencional de atuar contra o outro somente pode estabelecer-se, entretanto, pela mediação do objeto. Isto é, o objeto conhecido da relação de tolerância é o destinatário direto da abstenção de reação, mas, ao fim e ao cabo, deixa-se mesmo de reagir contra ele para não atacar o sujeito passivo - o destinatário indireto da suspensão da reação.

A ideia é esta: quando, por exemplo, deixamos intencionalmente de proibir a circulação de uma revista pornográfica no seio da sociedade, estamos abdicando de atuar diretamente contra a própria revista e seu conteúdo, e, indiretamente, contra os seus leitores e os seus produtores. Quando, no mesmo sentido, deixamos intencionalmente uma minoria étnica propagar entre os seus o valor cultural da supremacia do homem em relação à mulher, estamos suspendendo uma reação direta contra esse valor sociocultural específico e suas consequências para não atacar, indiretamente, as pessoas que o partilham e nele acreditam. O objeto da tolerância, seja ele qual for, é sempre o meio pelo qual o comportamento do sujeito ativo tem lugar, e essa é mais uma razão por que deve a sua existência ser suficientemente conhecida pelo sujeito tolerante.

Ora, essas considerações nos lançam diretamente para o último elemento constitutivo da categoria tolerância: é preciso que o sujeito ativo intencionalmente abstenha-se de atuar contra o outro (IV) com base em um fundamento axiológico.

Com efeito, eventualmente todos nós em algum momento de nossas vidas já nos questionamos acerca 
da razão de termos deixado de reagir de maneira mais impulsiva quando, em certas situações, relevantes convicções axiológicas que partilhamos foram tocadas negativamente pelas crenças, práticas ou valores propagados por outras pessoas.

Não é raro este tipo de questão nos ocorrer ao deitarmos à cabeça no travesseiro e, frequentemente, acabamos chocados com a sua aparente paradoxalidade: afinal, porque deixei de reagir agressivamente contra o motorista que realizou uma manobra perigosa em minha direção e pôs-me a correr riscos desnecessários? Ou porque não fui mais ríspido na resposta à grosseria do meu colega de trabalho?

Por que isto acontece? É dizer, por que nessas situações acabamos por preferir uma abstenção a uma reação mais efetiva contra quem nos vilipendia em algum sentido? Sem embargo, certamente as neurociências, a psicologia social ou as ciências sociais nos dariam respostas bastante interessantes e convincentes para essa interrogação, mas uma entre todas as possíveis, de fato, nos parece determinante para orientar nosso comportamento no sentido dessa abstenção de reação: cremos firmemente, e por alguma razão essencial de base, que “seria errado não tolerar o que é errado" (FORST, 2009, p. 19).

Isto é, em contextos tais em que somos confrontados com o barulho do vizinho, com o consumo de tabaco pelo nosso filho, ou com a rispidez de um marido em relação à esposa, embora tocados em nossas crenças e convicções essenciais, um ou vários fundamentos axiológicos nos dão boas razões para pensar que o mais correto é de fato não interferir, e só em virtude da sua existência e maior densidade axiológica relativamente às convicções tocadas é que conseguimos suspender a possível investida negativa (VALDÉS, 1992).

Nestes casos, por exemplo, podemos hipoteticamente pensar que manter a boa convivência comunitária, preservar o crescimento autônomo e refletido do nosso filho, ou respeitar a intimidade e a privacidade de um casal sejam fundamentos suficientes para abstermo-nos de reagir com efetividade na defesa das nossas crenças de que: a) não se deve incomodar o sossego alheio; b) não se deve ser permissivo com os filhos; ou, c) não se deve ser grosseiro com a esposa.

Com efeito, este fundamento axiológico ao qual nos referimos o reconhece, ora mais, ora menos explicitamente, praticamente toda a doutrina. David Heyd (1996), por exemplo, trata-o como uma espécie de second-order reasons às quais o sujeito tolerante apela para sopesar o juízo negativo inicial, enquanto Rainer Forst e Preston King veem-no como uma componente de aceitação que reequilibra a balança do agir / não reagir. A ideia subjacente, entretanto, é essencialmente esta:

o componente de objeção precisa ser balanceado por um componente de aceitação, que não remove o juízo negativo, mas fornece algumas razões positivas que superam as negativas em um contexto relevante. De acordo com essas razões, seria errado não tolerar o que é errado, para mencionar outro paradoxo bem conhecido da tolerância. As práticas ou as crenças em questão são erradas, mas não intoleravelmente erradas (FORST, 2009, p. 18).

Isso significa que só pode haver relação de tolerância se a abstenção intencional de atuação contra o 
outro, pela mediação do objeto, estiver fundada num valor, princípio ou crença mais forte que o valor vilipendiado e que leve o sujeito tolerante, mediante uma ponderação racionalmente prático-prudencial, a concluir pela validade desta sua abstenção (COHEN, 2004).

Aliás, esta é a razão pela qual manifesta-se Torres Ruiz (1986) ${ }^{13}$ no sentido de considerar semelhantes os modos de atuação concreta do sujeito tolerante e do sujeito prudente, embora - como acentua Ana Margarida Gaudêncio - a tolerância enquanto originariamente sophrosyne constitua algo diverso "da virtude intelectual prática da phronesis [...], porém ligada a esta, atenta a distinção entre virtudes morais (ou de carácter-expressão de ethos) e virtudes intelectuais (ou de razão - expressão de dianoia), em sede da bipartição da alma racional" (GAUDÊNCIO, 2012, p. 53).

Com efeito, esse fundamento axiológico relevante pode ser de vários tipos: um valor moral, uma crença religiosa, um princípio jurídico, etc. Indispensável, contudo, é que esteja realmente presente, pois, caso contrário, já não teremos mais uma relação de tolerância e, sim, talvez mera neutralidade (COHEN, 2004).

Daí porque também consideramos, novamente com Forst, que a tolerância constitui mesmo "um conceito normativamente dependente, o qual, para que tenha um determinado conteúdo (e limites especificáveis), carece de recursos normativos adicionais que não sejam dependentes nesse mesmo sentido" (FORST, 2009, p. 18).

$\mathrm{Na}$ posse de todos estes elementos, estamos, então, em condições de poder alcançar um conceito analítico possível. E, em nosso entender, outro não será este conceito senão aquele em que a tolerância passa a ser compreendida verdadeiramente como uma (I) relação entre dois sujeitos em que um, (II) pela mediação de um objeto conhecido, (III) intencionale (IV) fundadamente abstém-se de atuar contra o outro.

É dizer: para nós, a tolerância constitui analiticamente uma relação, uma cujo núcleo essencial reside num certo tipo de comportamento necessário (a não reação) que pode ter como fundamento possível de sustentação uma virtude ética, um princípio moral, jurídico ou político, ou, ainda, e sem esgotar as possibilidades de motivação racional, um dogma religioso

Ora, se a tolerância deve, então, ser compreendida como uma relação, praticá-la significa ou pode significar exatamente o quê? Bem, para nós, nada além do que concretizar o elemento central previsto pelo conceito: a suspensão de reação. Quer dizer, praticar a tolerância significa rigorosamente abster-se (III) intencional e (IV) fundadamente de atuar, (II) pela mediação de um objeto conhecido, (I) contra um outro.

Estes são os elementos e o conceito de tolerância, mas a sua prática carece de determinadas condiçóes de possibilidadepara ser concretizada. São duas, para nós, essas condições.

Em primeiro lugar, é preciso existir um contexto de (A) diversidade mínima. Isto é, eu só posso ter uma relação de tolerância se existir um outro, minimamente diverso de mim, a tolerar. Essa diversidade é sinônimo de 
pluralismo cultural ou de valores com o sentido de ter esse contexto social de ser deveras heterogêneo? Não necessariamente, embora neste tipo de sociedade a prática da tolerância seja mais indispensável e talvez ocorra com mais frequência.

Com efeito, essa diversidade a que nos referimos consiste na diversidade mínima que existe em todas as sociedades, mesmo nas mais culturalmente homogêneas, como consequência do fato de sermos capazes todos nós, em virtude da nossa indeterminação intencional e da nossa abertura ao mundo, de inserir a novidade no mundo. Ou, que o mesmo é dizer: a nossa existência "é um initium, e início que continua e essencialmente se retoma na existência: cada homem é novo (um homem novo) e novador (um ser de novidade)" (NEVES, 2008, p.33).

Em segundo lugar, neste contexto de mínima diversidade, é preciso que as pessoas (B) sejam efetivamente livres. Isto é, eu só posso intencionalmente tolerar o outro pela mediação de um objeto conhecido se, de fato, tiver a possibilidade de me autodeterminar nesse sentido, pois "que sentido tem o 'dever, a exigência normativa, sem o 'poder??" (NEVES, 2008, p. 32).

É necessário, entretanto, que eu tenha todas as minhas liberdades públicas garantidas e respeitadas para só então ter a condição de praticar a tolerância? Pensamos que não, embora no domínio prático a que estas liberdades tolhidas se aplicam já esteja descartada qualquer possibilidade de eu praticá-la (a tolerância).

Por outras palavras: se eu não possuo a liberdade de poder exercer meu direito de voto na escolha dos governantes da minha comunidade política, não existe a possibilidade de eu poder escolher entre abster-me ou não abster-me de tentar a sua substituição democrática. Eu o aceito, ou simplesmente me resigno em não poder interferir, mas nunca o tolero. Contudo, isso não significa, já, que não possa tolerar o meu vizinho, pois embora não possua essa relevante liberdade pública de natureza política, continuo possuindo a possibilidade de poder intencionalmente abster-me ou não abster-me de reagir contra ele.

Em suma: incapacitado de poder intencionalmente optar entre abster-me ou não abster-me de reagir contra um outro que me vilipendia essencialmente pela mediação de um objeto, já não estarei em condição de praticar a tolerância, mas, eventualmente, aquiescência (GAUDÊNCIO, 2012).

\section{A Dependência Normativa da Categoria Tolerância}

A noção de que a tolerância constitui um conceito normativamente dependente assimilamos da proposta de Rainer Forst. Sintetizando apertadamente algumas das suas ideias, diríamos que defende o seguinte: 1) a tolerância não configura um conceito amorfo, isto é, tem uma forma conceitual determinada e elementos constitutivos especificáveis; 2) neste conceito, identificam-se três componentes normativas importantes - 
objeção, aceitação e rejeição; 3) estas componentes constitutivas essencialmente normativas não se preenchem a si mesmas e não vêm preenchidas à partida no conjunto do próprio conceito, é dizer, os fundamentos que levam alguém a objetar certo comportamento, a contrabalancear essa objeção com algumas razões positivas para tolerálo, ou a rejeitá-lo inteiramente são buscados em sistemas normativos exteriores, tal como a moral, a religião, o direito, etc. ${ }^{13}$; 4) este recurso normativo adicional, entretanto, precisa observar dois requisitos indispensáveis tanto deve ser normativamente independente quanto autossustentável, e isto no sentido de que deve ser capaz de estabelecer de modo imparcial os limites da tolerância, assim como de torná-la vinculante mesmo em contextos de conflito ético relevante.

Sem embargo, a tese de Forst $(2013 ; 2014)$ nos parece lograda em vários aspectos e por muitas razões, mas, de fato, se pudermos destacar uma das suas virtudes, ou pelo menos a mais imediatamente relevante para nós, diríamos ser esta: ter ele reconhecido - embora não tenha sido o único - que nós objetamos, aceitamos e/ou rejeitamos algo ou alguém somente porque existem "três elementos essenciais" capazes de nos dar, na sua possibilidade de receberem "fundamentos normativos" diversos, boas razões para fazê-lo.

Quer dizer, no fundo só há possibilidade de existir objeção, aceitação até certo limite e/ou rejeição de algo ou alguém, diz ele, em virtude de existirem sistemas normativos externos e independentes de onde recolhemos fundamentos vinculantes que não vêm conceitualmente definidos.

Reconhecer, entretanto, estes aspectos positivos não implica, da nossa parte, que sejamos integralmente subscreventes do seu pensamento. Aliás, anteriormente já tivemos oportunidade de nos demarcar de uma das suas teses: para nós, a tolerância constitui verdadeiramente uma relação, ainda que uma relação de ausências, mas uma (I) relação entre dois sujeitos em que um, (II) pela mediação de um objeto conhecido, (III) intencional e (IV) fundadamente abstém-se de atuar contra o outro.

Com efeito, e diferentemente de Forst, compreendemos, em primeiro lugar, que só há dois terrenos normativos em um contexto de tolerância: um ocupado pelo objeto conhecido e axiologicamente refutável, e outro ocupado pelo fundamento axiológico justificador da não reação. Este nosso argumento pode ser melhor compreendido se o leitor imaginar a figura de uma balança: de um lado, temos o espaço a ser ocupado por um fundamento normativo que nos dirá, por exemplo, acerca do equívoco ou erro num sentido relevante da prática levada a cabo pelo sujeito passivo; de outro lado, temos o espaço a ser o ocupado por um fundamento normativo que nos dirá para não reagir contra este sujeito passivo pela mediação do objeto.

Teremos tolerância, ou intolerância, conforme o peso dos fundamentos axiológicos colocados em cada um dos lados. É dizer, se a balança pender para o primeiro lado, estamos então diante de um fundamento provavelmente muito caro e que nos vincula a uma reação; se, entretanto, a balança pender para o segundo lado, então certamente há fundamentos mais pesados a motivar-nos a não reagir contra o sujeito passivo. 
Dessa ideia conseguimos extrair algumas implicações interessantes, e que nos distanciam - embora não seja exatamente essa a nossa intenção - da proposta do autor.

Em primeiro lugar, só teremos tolerância se a balança pender para o segundo lado. Para nós isto significa, contrariamente ao entendimento de Forst, que o conteúdo essencial da tolerância é este invariável 'fundamento axiológico’ mais 'não reação contrả. Eu só posso não reagir contra alguém em razão de um fundamento forteque me determina nesse sentido, e tal conjugação é constante. A natureza do fundamento a me determinar no sentido da tolerância é que pode ser diversa e variável conforme o sistema normativo independente de onde eu o recolha, mas isso não torna alterável um conteúdo necessariamente estável.

Em segundo lugar, podemos perceber - e isso a proposta de Forst como a de outros já permitia - que os recipientes da balança são vazios e podem receber, digamos impropriamente, "qualquer conteúdo". Ou seja, os fundamentos para rejeitar fundadamente e para tolerar tanto podem provir de um mesmo sistema normativo independente, quanto podem eventualmente ser recolhidos de sistemas normativos distintos.

Traduzindo esta afirmação num exemplo, isto significa que eu posso invocar: (a) uma razão moral para rejeitar a prática de se manter relações sexuais com pessoas do mesmo sexo e um fundamento moral mais denso para tolerá-la; como posso, por outro, (b) ter a mesma razão moral para objetá-la e já invocar uma razão religiosa mais forte para justificar a sua tolerância. Ora, com isso queremos dizer que os fundamentos colocados em cada um dos recipientes da balança são completamente independentes um do outro e não precisam advir do mesmo lugar.

Mas não cingimo-nos somente a este aspecto. Também queremos dizer, em terceiro lugar, que a natureza do fundamento normativo determina, se invocado para tolerar ou intolerar, o tipo de tolerância ou intolerância em questão. Pensemos a partir da seguinte situação.

Digamos, por exemplo, que a prática de ter relações sexuais com pessoas do mesmo sexo constitua, para mim, um erro ou equívoco em sentido relevante (um pecado), pois agride o dogma da minha religião segundo o qual nós só devemos nos relacionar sexualmente com pessoas de sexo distinto em virtude de ser esse um ato sagrado e carecedor do mais elevado cuidado. Esse dogma religioso representa, para mim, um fundamento axiológico importante e suficiente para instaurar, no âmbito das relações intersubjetivas, uma divergência essencial de base com quem se relaciona sexualmente com pessoas do mesmo sexo.

Ocorre, entretanto, que eu posso ter na minha própria religião, assim como em diversos outros sistemas normativos independentes - como já vimos -, múltiplas razões para tolerar quem se relaciona sexualmente com pessoas do mesmo sexo. É possível, desde logo, que exista: (i) na minha religião um dogma segundo o qual não devemos julgar nossos semelhantes, pois isto é tarefa de Deus; (ii) no meu sistema moral, um valor segundo o qual nós devemos respeitar a intimidade e a vida privada de todos indistintamente; ou, (iii) no meu sistema ético, 
uma virtude segundo a qual a vida boa depende da paz e da harmonia com outras pessoas.

Cada um destes fundamentos, mediante uma ponderação interna, me diz e me determina a optar por uma não reação ao invés do seu contrário, isto é, todos eles me levam a toleraro pecado religioso da prática de se manter relações sexuais com pessoas do mesmo sexo. O âmbito em que esta não reação terá lugar já vem determinado? Não! É perfeitamente possível, por exemplo, que invocando o valor moral do respeito pela intimidade e privacidade das pessoas, deixe de reagir contra quem peca mantendo relações sexuais com pessoas do mesmo sexo (i) no próprio âmbito religioso, (ii) no âmbito moral, (iii) no âmbito ético, (iv) no âmbito jurídico, ou em qualquer outro.

Quer dizer, apoiado hipoteticamente no fundamento moral de que devo respeitar a intimidade e a privacidade das pessoas, eu tenho a possibilidade de não reagir contra quem pratica o pecado de manter relações sexuais com pessoas do mesmo sexo no próprio plano da minha religião, deixando, por exemplo, de impedir que homossexuais frequentem minha igreja; como tenho a possibilidade de também não reagir em outros planos, tal como o jurídico, deixando, por exemplo, de denunciar às autoridades competentes, caso esta prática constitua infração penal, a sua ocorrência e os seus autores. Em suma: a natureza do fundamento normativo invocado para tolerar não determina o domínio prático em que a tolerância terá lugar.

Mas é preciso ter em conta, entretanto, que esse fundamento normativo invocado para tolerar determina um tipo de tolerância que estarei a praticar, ainda que tenha ou possa ela ter lugar em diversos âmbitos da praxis. Quer dizer, no caso do exemplo acima, o fato de eu deixar de reagir, em virtude de um fundamento moral, no âmbito religioso ou jurídico contra quem pratica o pecado de manter relações sexuais com pessoas do mesmo sexo não torna esta tolerância genuinamente moral, e só por esse fato, em tolerância religiosa ou tolerância jurídica.

Para nós, tanto quanto a natureza do fundamento normativo invocado para tolerar não delimita o âmbito de incidência da tolerância, também este domínio prático de incidência não tem o condão de descaracterizar o tipo de tolerância que o fundamento de sustentação determina. É dizer: a natureza de cada fundamento normativo invocado especifica um tipo tolerância. Se eu substituo, ainda no exemplo acima, o valor moral pelo dogma religioso ou pela virtude ética, já não mais terei uma tolerância moral, senão uma tolerância religiosa e outra tolerância ética que igualmente poderão incidir nos diversos âmbitos da prática.

Ora, se é mesmo verdade que em certa altura o homem ocidental diferenciou e autonomizou as dimensões constitutivas do seu mundo prático de intersubjetividade, temos então de forçosamente reconhecer que o sistema normativo de onde provém cada fundamento para tolerar dá ensejo a um tipo distinto de tolerância, pois, do contrário, ainda estaremos diante de uma "indiferenciação no global todo da especificidade de tudo" (NEVES, 1998, p. 24). 
Neste ponto poderia o leitor se questionar: bem, se assim o é, então o que diferencia constitutivamente estes tipos todos de tolerância? De que modo, e por qual razão, é a tolerância jurídica, por exemplo, distinta da tolerância moral?

Sem embargo, não estamos em condições de poder oferecer uma resposta conclusiva e satisfatória para esta pergunta, mesmo porque, embora relevante, esta não representa para nós uma questão central. Mas reconhecemos uma pista: sem dúvida, uma resposta possível passa necessariamente pela própria distinção entre direito, moral, religião, política, etc. Seja como for, todavia, é importante termos claro o seguinte: a natureza de cada fundamento normativo invocado determina um tipo de tolerância possível.

Com efeito, essa relação de tolerância não tem só um tipo específico como é, igualmente, única, e isto no sentido de que alterados o objeto e/ou os fundamentos invocados para rejeitar ou tolerar, o produto da ponderação necessariamente será outro. Mais uma vez a imagem da balança nos ajuda a entender: se a minha decisão de reagir ou não reagir contra o sujeito passivo depende de uma ponderação específica entre dois fundamentos axiológicos - um a instaurar a divergência essencial de base, e outro a determinar a tolerância -, alterando estes fatores ou objeto sobre o qual incide as valorações posso ou não continuar a ter o mesmo resultado.

Isto é, no caso do exemplo anterior, da ponderação entre um dogma religioso segundo o qual nós apenas devemos nos relacionar sexualmente com pessoas de sexo distinto, e um fundamento moralde que devo respeitar a intimidade e a privacidade das pessoas, só foi possível termos tolerância porquanto eram estes os recursos normativos envolvidos e era aquele o objeto (manter relações sexuais com pessoas do mesmo sexo); alterados todos ou apenas alguns, quiçá a balança não se mantivesse pendente para o segundo lado.

Isso significa que numa ponderação entre o mesmo dogma religioso, mas já agora envolvendo outro fundamento moral ou mesmo um determinado princípio jurídico, a opção pela tolerância talvez não se mantenha, e se se mantiver, já será uma outra relação de tolerância de outro tipo.

Com efeito, esta implicação nos deixa em condições de perceber algo muito importante acerca da dependência normativa da categoria tolerância: a de que podemos, em virtude de cada fundamento invocado, tolerar ou não tolerar o mesmo objeto. Isto é, pode um determinado fundamento moral, na ponderação com o dogma religioso, pesar a balança no sentido da tolerância do objeto, como pode outro fundamento moral ou já um fundamento jurídico pesar menos, expondo-nos então a um contexto de intolerância religiosa.

Daí poderá o leitor nos questionar: bem, se cada relação de tolerância é única, então qual será o limite desta nossa tolerância moral relativamente à prática do pecado de se manter relações sexuais com pessoas do mesmo sexo? Sem embargo nós diríamos que esta relação de tolerância tem os seus limites no conjunto de intolerâncias que vamos manifestando no âmbito da nossa interação intersubjetiva com vistas a delimitar o espaço 
em que pode o sujeito passivo agir sem sofrer retaliações.

Vale dizer, tal como Forst, também entendemos que o limite da tolerância está na intolerância, mas dele divergimos na medida em que, para nós, estes limites não estão no terreno normativo da rejeição - também este um elemento constitutivo do conceito analítico de tolerância; encontram-se, na verdade, externamente no conjunto de intolerâncias que vamos manifestando com vistas a delimitar o espaço em que pode o sujeito passivo agir sem ser retaliado.

Ora, mas dizer isso ainda não especifica exatamente quais são esses limites. Bem, para nós esses limites não são fixos e oscilam conforme o fundamento normativo utilizado para intolerar ${ }^{14}$. É dizer, o espaço em que o outro poderá agir sem sofrer reações negativas dependerá dos fundamentos normativos que se vá invocando e dos juízos de intolerância que se vá manifestando acerca dos objetos. Não encontra-se esse espaço perfeitamente delimitado à partida; ele vai sendo demarcado na medida em que as situações e os objetos vão surgindo e acerca deles vai ajuizando o sujeito ativo.

Esta, portanto, as implicações fundamentais decorrentes do fato de ser a tolerância um conceito normativamente dependente.

\section{A RELAÇÃO ENTRE A TOLERÂNCIA E O DIREITO}

A partir do que estabelece a literatura, é possível constatar, em nossa opinião, que a relação entre a categoria tolerância e o domínio do direito pode se estabelecer de três modos essenciais. Com efeito, não são esses três modos, para nós, os únicos existentes; constituem, na verdade, apenas três formas possíveis dentre muitas outras, com a só diferença de que tais formas já foram objeto de análise pela doutrina.

Ora, o primeiro (3.1) modo de relacionação possível entre a categoria tolerância e o domínio do direito tem que ver precisamente com o fato deste último representar um limite possível, dentre vários outros, à certas formas de intolerância, ou à certos modos e/ou intensidades com que poder-se-á manifestá-la. Veremos porque é assim.

O segundo (3.2) modo, por sua vez, respeita à possibilidade, sendo a tolerância uma categoria normativamente dependente, de se recolher do sistema normativo 'direito' um fundamento axiológico para tolerar - circunstância na qual a tolerância assimilará o direito para projetar uma tolerância de natureza eminentemente jurídica, embora suscetível de ter lugar em vários domínios práticos.

O terceiro (3.3) modo de relacionação possível temos quando, ao contrário do segundo, é o próprio direito quem assimila a tolerância para: a) compreendê-la uma parte constituinte de si, e isto enquanto princípiojus; ou, b) vislumbrá-la uma parte integrante de si, enquanto princípio-intentio de origem extrajurídica (moral, 
ética, religiosa, etc.); ou, por fim, c) entendê-la parte integrante de si enquanto conteúdo de critério normativo positivado capaz de ser diretamente mobilizado no concreto juízo decisório (GAUDÊNCIO, 2012) ${ }^{15}$.

\section{O Direito (enquanto Validade) como um Limite da Intolerância: a Mundividência Jurisprudencialista}

Dissemos, portanto, que o direito representa um obstáculo, ou impõe limites à intolerância. Significa isso dizer que será ele o único sistema normativo a limitá-la? Não, evidentemente! É absolutamente possível que a religião, a política, a moral ou a ética também imponham limites à intolerância - aliás, cremos mesmo que o fazem.

Com efeito, nem o direito constitui o único limite da intolerância - é apenas um dentre outros possíveis -, como nem todas as formas, modos ou intensidades de intolerância serão por ele limitadas. Isto é, o direito imporá limites somente à intolerância que manifeste relevância jurídica (KAUFMANN, 2010) ${ }^{16}$.

Isso significa que uma reprimenda verbal dirigida a um vizinho como forma de intolerância com o fato de ele circular trajado apenas em roupas íntimas pelo andar compartilhado não estará, à partida, limitada pelo direito - poderá estar, como dissemos, por outros sistemas normativos. Mas estará vedada, porque dotada de relevância jurídica, a reprimenda verbal que eventualmente veicule uma ofensa à sua honra.

Ora, se assim o é, então quais são esses limites? Onde os encontramos?

Sem embargo, diríamos encontrá-los todos ao nível do sistema jurídico comunitário ao qual estamos adstritos e do qual somos protagonistas-participantes (HART, 1994; NEVES, 1976; LINHARES, 2008). Sendo um pouco mais específico, isto corresponde a dizer que os limites e condicionamentos das manifestações de intolerância dotadas de relevância jurídica são encontrados dispersamente por todos os domínios do sistema de direito ao qual estamos vinculados, como, por exemplo, ao nível do direito penal e na especial proteção conferida, pela via das penalizações jurídico-criminais, a certos bens e valores jurídicos; ao nível do direito civil e na especial proteção conferida, pela via do mecanismo da responsabilidade civil, a estes mesmos bens jurídicos ou a outros aos quais esteja vocacionado a proteger, e assim por diante.

Para nós, entretanto, mais importante do que interrogar por estes limites visando a sua identificação é perguntar pelo porquê de existirem e de nos vincularem. Isto é, por-quêo direito e por qual razão/fundamento ele (o direito) nos obriga a respeitar limites? Como se vê, trata-se, agora, de interpelar o próprio direito para questioná-lo - como dirá Castanheira Neves (2008; 2010; 2011) - pelo constitutivo, no conjunto das suas condições de possibilidade, que o faz emergir com o sentido normativamente material que o constitui como direito.

Com efeito, no âmbito da mundividência jurisprudencialista ${ }^{17}$, e o que a respeito dela ajuíza e constrói 
Castanheira Neves, seriam três essas condições de possibilidade - uma condição mundanal, uma condição antropológico-existenciale uma derradeira, mas também eventual, condição ética. Sintetizemo-las.

1) É a condição mundanal a primeira delas e a expressão irrecusável de uma perplexidade factual com que afinal todos nós nos defrontamos: "O mundo é ume os homens nele são muitos" (NEVES, 2008, p. 13). Pelo que coabitando pluralmente a unicidade do mundo, impõe-se-nos que tanto nele convivamos quanto, e principalmente, partilhemo-lo - somos todos socii-sócios no mundo.

Essa escassez de mundo (HART, 1994), todavia, não nos determina um qualquer modo de habitação e partilha; antes, impõe um certo modo de coabitação e comunhão em que tanto nos vemos numa conjugação de esforços para coletivamente aceder à fruição do mundo, quanto, e também, numa obstrução mútua para fruí-lo de forma individual (NEVES, 2008).

Isto significa que

"a existência humana no mesmo mundo é elementarmente uma existência de intersubjectividade. [...] Inter-subjectividade [que] refere a reciprocidade entre ambos, de tal modo que a situação ou o comportamento de um condiciona a situação e o comportamento de outro" (NEVES, 2008, p. 13).

2) Enquanto esta condição mundanal antecipa, na especificação dessa nossa vocação para a intersubjetividade, a nota inconfundível da jurídica bilateralidade atributiva (REALE, 2002) - e bem assim da índole marcadamente social do direito ${ }^{18}$ (VALE, 2011) -, a condição antropológico-existencial (a segunda das condições de possibilidade do jurídico) nos aparecerá para confirmar uma imagem do homem enquanto ser não apenas indeterminado como, igualmente, aberto ao mundo.

Com efeito, a característica da indeterminação intencional traduz o fato de inexistir "uma acabada determinação ou codificação do comportamento humano de adaptação ao meio, [...] e que parecendo assim manifestar uma carência biológica", já por isso força-o a construir uma espécie de segundo habitat-precisamente o habitat da cultura (das referências simbólicas comuns) e, nela, do mundo prático (dos referentes normativos partilhados) - para terminar a sua determinação comportamental (NEVES, 2008, p. 16).

A nota da abertura ao mundo, por sua vez, radica na ideia de que, sendo o homem intencionalmente inespecializado, e, portanto, ao fim e ao cabo livre, está ele em condições de poder superar-se a si mesmo (de transcender; é ser de transcensão) - e isto em virtude da "possibilidade [que possui] de objectivar a sua experiência e de a superar num plano ideal, de a escrutinar racionalmente e de a compreender em termos espirituais" - intencionando (projetando para o futuro), assim, ser algo distinto daquilo que é (VALE, 2011, p. 87).

Ora, esta intenção a outro nível de ser mais não é que uma intenção à plenitude, pelo que, enquanto apelo ou expressão da dialética finitude/transfinitude, há de converter-se verdadeiramente num dever-de-ser, ou 
num valor ${ }^{19}$.

Ocorre, entretanto, que essa plenitude de ser só pode o homem atingi-la no contexto de uma comunidade, e esta enquanto concreta manifestação material do nosso modo essencial de existir (NEVES, 2008). Isto porque, em primeiro lugar, essa comunidade nos aparece como uma condição de existência, configurando o meio "directo da nossa actuação e comunicação, critério imediatamente disponível de orientação e compreensão e com base no qual pré-determinamos e providenciamos a nossa práxis comum" (NEVES, 2008, p. 21); em segundo lugar, porque também constitui para nós uma condição vital, ao prover-nos dos recursos materiais que só a colaboração de todos propicia; em terceiro lugar, porquanto configura, ainda, uma nossa condição ontológica no sentido de que "só em comunidade é possível conjugar as potencialidades humano-espirituais, através da síntese dos contributos de cada um de nós e de todos, para a plena realização de cada pessoa" (NEVES, 2008, p. 24).

Ora, a conjugação da condição mundanal com a condição antropológico-existencial expõe-nos diante de um problema: como tornar possível a convivência e a coabitação no mesmo mundo de homens dispersos e indeterminados? Através de uma ordenação da nossa fruição intersubjetiva do mundo, responderá Castanheira Neves. É dizer, "seres indeterminados, dispersos e de contínua variação, e que são assim numa imensa pluralidade, só poderão conviver num mesmo mundo através da criação" de uma ordem, uma em que afinal a unidade e a integração substituam a pluralidade e a dispersão, e bem assim a indeterminação intencional se veja superada pela objetivação dogmática e a variação pela institucionalização (NEVES, 2010, p. 298).

3) Sem embargo, enquanto as duas condições anteriores são incontornáveis em virtude de identificarem "um problema constante para o homem que é o da ordenação do acesso ao mundo e das relações intersubjectivas que a sua fruição origina", a terceira caracterizar-se-á apenas como uma condição eventual, e isto no sentido em que é o resultado de um compromisso cultural, ou de um projeto de ser civilizacionalmente específico (VALE, 2011).

Isto é, somente havemos de ter uma ordem de direito com o seu sentido constitutivamente axiológiconormativo quando, e enquanto, se permitam os homens reciprocamente reconhecerem-se como pessoas nas suas respectivas dignidades, como verdadeiros fins em si mesmos e não apenas coisas disponíveis - trata-se agora de uma derradeira e especificamente constitutiva condição ética. O direito só pode existir entre homens-pessoa e para tornar viável a integrante coexistência intersubjetiva de homens-pessoa - não há direito para coisas.

E isso porque consubstancia a pessoalidade, enquanto aquisição axiológica que é, um ideal normativo acerca do modo como nós, enquanto seres humanos, nos devemos tratar no âmbito das "nossas relações intersubjectivas a propósito do mundo" (NEVES, 2010, p. 298) - razão pela qual se justifica dizer "[...] segundo o enunciado de HEGEL, que 'o imperativo do direito é este: sê pessoa e respeita os outros como pessoas'” (NEVES, 2008, p. 41) 
Com efeito, o reconhecer-se pessoa significa reconhecer-se a si mesmo e aos outros, e ser por eles também reconhecido, tanto como um eu pessoal de autonomia e liberdade, quanto, igualmente, como um eu comunitário de responsabilidade e dever. A pessoa do direito só é nesta sua autonomia e nesta sua responsabilidade, nos seus direitos e igualmente nos seus deveres (NEVES, 2008)

Deste reconhecimento da nossa pessoalidade na sua estrutura bidimensional decorrem, portanto, e desde logo, duas implicações normativas fundamentais, cada uma referente a um dos polos apontados. Em primeiro lugar, e por um lado, desponta um princípio de igualdade, a traduzir a ideia segundo a qual nenhum homem-pessoa vale mais do que outro, e todas as suas eventuais diferenciações devem se justificar "perante essa igualdade entre pessoas". Em segundo lugar, e por outro ladro, desponta também um princípio de responsabilidade, a convocar a nossa corresponsabilidade "pela totalidade de intenções e valores" para os quais comunitariamente, e na comunidade, concorremos (NEVES, 2008).

Ora, esta derradeira condição ética, com as suas muito específicas implicações normativas, nos permite vislumbrar qual o significado (ou sentido) que o direito tem para o homem e com o qual deverá ele ser assumido. E dir-se-á, quanto a este sentido, que ele somente estará adequadamente compreendido se tiver em conta o direito, verdadeiramente, enquanto uma validade.

Isto é, o direito constitui uma validade porque, na sua intenção ao justo e não ao injusto, ao lícito e não ao ilícito, ao devido e não ao indevido, se torna para o homem um fundamento que o vincula e the diz como deve (inter)agir. O que de outra forma corresponde o mesmo a dizer: se nenhuma pessoa vale mais do que a outra, e se todas são responsáveis pelo cumprimento de intenções materiais comunitárias, as pretensões e exigências que reciprocamente uns dirijam aos outros só poderão ser cumpridas por força de "um fundamento axiológiconormativo que não pretira e antes satisfaça a dignidade e a igualdade, que perante estas validamente justifique a posição ou pretensão" (NEVES, 2008, p. 39) ${ }^{20}$.

Em uma só palavra, portanto: o ser validade significa, ao fim e ao cabo, reconhecer o direito como um fundamento para as pretensões que, enquanto pessoas, reciprocamente nos dirijamos a propósito da nossa fruição intersubjetiva do mundo.

Pois bem, este é o significado (ou sentido) geral com o qual deverá o homem assumi-lo, mas só com isso ainda não se resolve uma questão mais profunda e que será precisamente a de saber qual será "fundamento que sustentará essa validade", é dizer, a de saber qual constituirá o fundamento do fundamento (NEVES, 2012, p. 68).

Ora, a resposta que caberá para essa questão será precisamente esta: o direito só se constitui numa validade e só se torna um fundamento vinculativo para o homem porque na sua intenção à justiça, à licitude e ao devido, assimila e assenta em certos valores e princípios que "pertencem tanto ao ethos fundamental como ao epistéme prático de uma certa cultura numa certa época”, e os quais o homem, vendo-se neles reconhecido, já 
"não pode dispor sem a si mesmo se negar" (NEVES, 2012, pp. 68-69)

Vale dizer, o direito constitui uma ordem de validade porque fundamenta-se nos valores e princípios transindividuais decorrentes do nosso compromisso axiológico-normativo último (e que será também o nosso projeto regulativo civilizacional) de nos reconhecermos e respeitarmos reciprocamente como pessoas - sem embargo, é na pessoa e nos princípios nos quais esta aquisição axiológica se traduz que está o fundamento da validade do direito, ou, se quisermos, o fundamento do fundamento (NEVES, 2012).

Ora, com isto temos já condições de compreender por qual razão ele há de nos vincular e há de impor limites à certas formas, modos ou intensidades de manifestação da nossa intolerância. É que, sendo o direito essa ordem material de validade, haverá ele de exprimir normativamente e projetar na realidade o sentido dos valores e princípios que decorrem daquele nosso compromisso vinculativo de nos tratar e respeitar reciprocamente enquanto pessoas.

Com efeito, toda manifestação de intolerância que ponha em causa, ao fim e ao cabo, um princípio no qual se traduz o valor da pessoa, ou que ponha em causa o próprio valor da pessoa, estará vedada - este é o limite que o direito lhe impõe. É dizer, as nossas manifestações de intolerância poderão ser limitadas por outros sistemas normativos, mas pelo direito apenas estarão limitadas essas que possuam relevância jurídica no sentido acima exposto.

\section{A Tolerância Jurídica}

O primeiro modo de relacionação possível entre a tolerância e o direito subsiste, portanto, no fato de este se impor limites à certas formas, modos ou intensidades com que se poderá manifestar a intolerância. O segundo modo, por sua vez, temos quando a tolerância absorve o direito para projetar uma tolerância de natureza jurídica, isto é, quando a prática da tolerância vai buscar no sistema normativo que o 'direito' constitui um fundamento axiológico relevante para se realizar.

Esta possibilidade assenta, como vimos antes, no fato de constituir a tolerância um conceito normativamente dependente que carece de um fundamento relevante normativamente independente para se sustentar. No que ao direito toca, esse fundamento tanto poderá constituir um critério-regra do sistema (uma lei, um ato normativo, um entendimento jurisprudencial ou doutrinário, etc.), quanto um princípio jurídico decorrente do nosso projeto prático-cultural de reconhecermos e respeitarmos enquanto pessoas.

No mais, será também essa tolerância jurídica uma relação única, limitada, e passível de ter aplicação em diversos outros os domínios que não o estritamente domínio do direito - remetemos o leitor para tudo o quanto foi dito a este respeito no tópico (2.1). 


\section{A Tolerância no Direito}

O terceiro modo de relacionação entre a tolerância e o direito temos quando, em nosso sentir, e diferentemente do anterior, o jurídico a assimila de modo a compreendê-la, lato sensu, parte integrante da ordem (ou do sistema) que objetivamente materializa. Isto é, enquanto no tópico precedente tratamos da possibilidade de o direito servir de fundamento para a prática da tolerância, agora, distintamente, iremos analisar a possibilidade de a tolerância ser assimilada pelo direito de modo a constituir um princípio e/ou critério.

Essa possível assimilação também pode se dar também de três formas.

A primeira, que rigorosamente não consiste em uma assimilação, se dá quando a tolerância é compreendida como uma parte constituinte do sistema jurídico enquanto um seu princípio-jus decorrente, ao fim e ao cabo, do sentido material com que o assumimos (ou do compromisso comunitário de tratarmo-nos e respeitarmo-nos como pessoas).

A segunda, por sua vez, esta já verdadeira assimilação, se dá quando a tolerância é assimilada pelo jurídico, mediante uma comunicação seletiva ou filtragem dos respectivos conteúdos, na forma de um princípio-intentio decorrente, afinal, "de exigências extrajurídicas orientadoras da criação e realização concreta do direito" (GAUDÊNCIO, 2012, p. 478).

A terceira, por fim, se dá quando a tolerância é assimilada pelo direito enquanto conteúdo de critério normativo positivado capaz de ser diretamente mobilizado no concreto juízo decisório. Analisemo-las todas.

\section{a) A tolerância enquanto princípio-jus}

De início, uma pergunta logo se impõe: que compreensão teórico-metodológica é esta dos princípios por meio da qual são eles entendidos como verdadeiros jus, ou autêntico direito vigente? Por que são compreendidos dessa forma?

Com efeito, bem sabemos que a maneira como os princípios são concebidos encontra-se intimamente relacionada com a perspectiva, ao fim e ao cabo, com a qual o próprio direito é compreendido ou assimilado pelo pensamento que o pensa. Na mundividência jurisprudencialista, e diferentemente de outras tantas perspectivas existentes neste quadro de pluralismo acentuado do pensamento jurídico, os princípios são encarados e afirmados verdadeiros, e originários, princípios normativos (NEVES, 2011).

É que, se o direito há mesmo de ser compreendido como uma ordem de validade, constituirão estes princípios as intenções axiológico-normativas (os valores transindividuais) em que esta validade, radicada no compromisso-último da pessoa, haverá de encontrar sua tradução prático-normativa, e cujos sentidos normativos 
deverá o direito projetar na realidade (BRONZE, 2002; LINHARES, 2012).

Isto é, nem são, por um lado, "meros ideais regulativos", "nem dados puramente imanentes ao positivado sistema jurídico", por outro; antes constituem traduções (ou objetivações axiológico-materiais) dos compromissos práticos (ou da ordem de validade) que a própria comunidade vai historicamente constituindo, revelando por meio da sua realização e estabilizando dogmaticamente como "orientações constitutivas fundamentais", no que se convertem, então, em fundamentos do sistema (VALE, 2011, pp. 103-104).

Ao assumir uma compreensão dos princípios normativos como autêntico direito vigente ao reconhecer nestes os fundamentos constitutivos da validade do direito [...] —, a reconstituição jurisprudencialista não só nos expõe, efectivamente, a uma experimentação permanente do excesso normativo dos princípios - enquanto intenções constitutivas de um normans (inesgotáveis nos critérios e nas realizações que fundamentam) - como também exige que ao problema do tratamento destes fundamentos corresponda uma experiência de constituição-manifestação-realização inconfundível (LINHARES, 2012, pp. 411-412).

São, portanto, compreendidos como autênticos jus (direito vigente) - assim dirá Castanheira Neves porque, ao fim e ao cabo, constituem estes princípios verdadeiras desimplicações normativas do nosso projeto civilizacional de nos reconhecermos e respeitarmos enquanto pessoas.

Ora, a compreensão da tolerância que, partindo desta perspectiva dos princípios, a encare enquanto um princípio normativo (ou princípio-jus), pretende ver nela um autêntico fundamento normativo e um momento constitutivo do direito (BRONZE, 2002).

Isto é, trata-se, na perspectiva que a compreenda dessa forma, de afirmá-la simultaneamente, tal como aponta Fernando Bronze... um princípio de direito, assim uma resposta ao problema da fruição intersubjetiva do mundo "consonante com a ideia de direito histórico-culturalmente (com-)partilhada" (BRONZE, 2002, p. 574))... e um princípio do direito, dessa maneira reconhecidamente vigente (válido e eficaz) pelo pensamento jurídico... capaz de ser por isso justiciável, e então apto a manifestar "a dimensão pragmática que [lhe distingue] dos meros valores" (BRONZE, 2002, pp. 582-583).

E de afirmá-la enquanto princípio normativo para reconhecer-lhe a possibilidade, como indicará Ana Margarida Gaudêncio: i) de constitutivamente fundamentar a criação de novo critério-regra; ii) de constitutivamente determinar a relevância ou irrelevância jurídica de um dado comportamento; e/ou, ainda, iii) de constitutivamente relevar como cânone jurídicono plano metodológico.

É dizer, enquanto princípio normativo e autêntico fundamento do sistema, não só a tolerância passa a constituir uma dimensão integrante de novos critérios-regra - na medida em que eles exprimem a sua operatividade dogmática, como se torna, também, componente do filtro de determinação do que deve ou não ser considerado relevante para o direito bem como, e ainda, passa a intervir na judicativo-decisória realização do direito, 
Em suma, portanto, também admitimos a possibilidade de vir a tolerância "se, onde e quando passe o crivo dogmático da determinação jurídica de conteúdo, se assumir como efectivo jus, e, nessa hipótese, como verdadeiro princípio normativo" (GAUDÊNCIO, 2012, p. 515).

\section{b) A tolerância enquanto princípio-intentio}

Também nesta linha de compreensão trata-se de "restituir" aos princípios a sua inconfundível dimensão axiológica, mas não apenas para afirmar que as suas intenções materiais "têm já um sentido prático-normativo" e são por isso comunitariamente relevantes, senão, antes, para reconhecer que consubstanciam exigências materiais à partida destituídas de juridicidade e, portanto, meras intenções regulativas que ao direito deveriam relevar (LINHARES, 2012).

Isto é, por esta perspectiva, sustenta-se que os princípios não possuem caráter ou natureza jurídica originária, pelo que não consubstanciam autêntico direito vigente, salvo "se se manifestarem em critérios positivos vinculantemente institucionalizados (a começar decerto pelas leis constitucionais)", ocasião em que receberão "destes (ou da autoridade-potestas que os sustenta) a sua força jurídica (ou a dimensão constitutiva que a traduz)" (LINHARES, 2012, p. 404).

Sem embargo, desta compreensão geral é possível destacar - assim entende Aroso Linhares - "duas possibilidades operatórias [distintas] (possibilidades que podem ser defendidas cumulativa ou separadamente, se não concebidas como meras diferenças de grau)" (LINHARES, 2012, p. 404).

Uma primeira, que vendo nos princípios manifestações de valores ou padrões ético-sociais, leva-os à sério enquanto expectativas materiais comunitárias para as quais deverá a entidade responsável pela criação dos critérios jurídicos e pela determinação de relevância ou irrelevância jurídica de uma certa matéria estar especialmente atenta (LINHARES, 2012, p. 404)..

E, uma segunda, que vendo neles ainda a manifestação de uma certa tipicidade ético-social, leve-os a sério enquanto indicações orientadoras ou cânones extrajurídicos de relevo na judicativo-decisória realização do direito - "indicações que, não constituindo como tal direito vigente, podemos convocar como apoios-arrimos [...] quando interpretamos uma norma legal ou um critério jurisprudencial... e muito especialmente quando temos que enfrentar um «caso omisso» e resolver um problema (dito) de integração" (LINHARES, 2012, pp. 404-405)..

Ora, a compreensão da tolerância que nessa perspectiva se afirme, pretende encará-la, assim aponta Ana Margarida Gaudêncio, como uma inconfundível intenção regulativa exterior a projetar-se no domínio do direito com o sentido de orientar tanto a jurídica produção dos critérios-regras, quanto a sua judicativo-decisória realização (GAUDÊNCIO 2012). E para orientá-lo, ponto importante a acentuar, mantendo a sua natureza 
extrajurídica (ética, moral e/ou religiosa) originária.

O que por outras palavras significa reconhecer, partindo desta perspectiva, a possibilidade e a capacidade de uma tolerância originariamente ético-moral, religiosa, etc.: i) orientar diretamente a criação de novo critérioregra; ii) inspirar a determinação de relevância ou irrelevância jurídica de um dado objeto; ou, por fim, iii) relevar como cânone extrajurídico no plano metodológico.

Com efeito, a nós nos parece ter razão Ana Margarida Gaudêncio (2012) ao considerar que as referências do pensamento jurídico a um princípio de tolerância, sem negar a possibilidade de vir a ser encarada enquanto um princípio jus, parecem se dar com base nessa específica compreensão dos princípios tal como esboçada.

Ora, o que é o princípio da insignificância penal, por exemplo, senão uma assimilação travestida do princípio da tolerância, e, neste caso, de uma tolerância compreendida de forma originariamente extrajurídica?

Sem embargo, embora saibamos que estiveram na sua origem diversos outros princípios normativos (legalidade criminal, intervenção mínima, lesividade, etc.), e embora ainda o resultado que possibilite seja mesmo o de excluir ou afastar a tipicidade penal material desconsiderando criminoso o ato praticado, o fato é que, ao fim e ao cabo, a conduta adotada pelo agente ainda permanece, pelo menos do ponto de vista formal, penalmente típica.

Com efeito, o que nos diz o princípio da insignificância penal é que as condutas formalmente típicas não expressivamente lesivas de bens jurídico-penais são toleradas pelo ordenamento jurídico e pela comunidade outra tradução possível, e jurídica, para um princípio de tolerância.

Em uma palavra, portanto, admitimos igualmente na linha da doutrina referenciada a possibilidade de vir a tolerância, compreendida enquanto um valor ético-social relevante, ser considerada pelo direito e, se for o caso, institucionalizada, quando assim manifestar o pensamento jurídico.

\section{c) A tolerância enquanto conteúdo de critério}

A terceira das possibilidades de assimilação da tolerância pelo direito ter-se-á quando, diferentemente das outras duas anteriores, ela se tornar conteúdo de critério-regra do sistema jurídico. Vale dizer, quando converterse, como dirá Ana Margarida Gaudêncio (2012, p. 576), em "critério normativo diretamente convocável para a decisão judicativa" quer sob a forma de "critérios legislativamente prescritos", quer sob a forma de "critérios jurisprudencial e/ou dogmaticamente elaborados".

Essa possibilidade tanto poderá decorrer de um eventual princípio normativo ou extrajurídico de tolerância, quanto de outro princípio normativo existente no sistema, mas nunca poderá, enquanto critério-regra, vir a exprimir um direito a ser tolerado correspectivo de um dever de tolerar. 
Isto porque, se é condição de possibilidade da tolerância a existência de liberdade para não se reagir contra, então não há como existir, por notória antinomia, um dever objetivo de tolerar. Mas isso não impede, entretanto, e por exemplo, que na base de um dever de respeito pela diferença, e consequente dever de abstenção de reação contra, não possa estar a exigência, jurídica ou extrajurídica, de tolerância - aliás, a liberdade religiosa e o dever de abstenção que ela nos impõe parecem mesmo resultar daí.

Mais uma vez o princípio da insignificância penal é um bom exemplo que nos ajuda a compreender. Isto porque, o afastamento ou exclusão da tipicidade material do ato como consequência prática da sua "aplicação" só pode ter lugar se a conduta em questão encontrar-se enquadrada em certos requisitos, tais como, por exemplo, e para jurisprudência brasileira: a) ter sido minimamente ofensiva; b) não ter tido nenhuma periculosidade social; c) ter grau de reprovabilidade reduzidíssimo; e, d) ter produzido lesão jurídica inexpressiva.

Ora, estes requisitos mais não são do que os próprios critérios-regras dogmaticamente estabelecidos para a operacionalização prático-normativa do princípio da insignificância penal, pelo que também acabam por constituir critérios em cujo conteúdo estará presente a categoria tolerância.

Em suma, portanto, admitir a possibilidade de a tolerância vir a ser assimilada pelo direito enquanto conteúdo implícito ou explícito de critério-regra do sistema jurídico significa, tão somente, reconhecer a possibilidade de que possa ser concretamente convocada/mobilizada na judicativo-decisória realização do direito.

\section{CONSIDERAÇÕES FINAIS}

Percorrido todo este trajeto, ficamos então em condições de poder oferecer uma resposta, senão, no fundo, ficamos em condições de poder voltar a insistir na resposta já oferecida para a questão principal que conduziu todo este estudo: como se pode estruturar a relação entre a tolerância e o direito no mundo prático do homem?

Ora, tal como restou exposto, não lhe caberá outra resposta senão a que referencie os três modos de estruturação apontados precedentemente. Isto é, a relação entre o domínio do direito e a categoria tolerância pode se estabelecer dos seguintes modos: a) com o direito a limitar certas formas de intolerância, ou certos modos e/ou intensidades com que poder-se-á manifestá-la - um modo, diríamos assim, transversalde relação, porque no fundo envolve não a tolerância, mas o seu oposto; b) com a tolerância a assimilar o direito - este o fundamento daquela - para projetar uma tolerância de natureza eminentemente jurídica; ou, ainda, c) com o direito a assimilar a tolerância para: i) compreendê-la uma parte constituinte de si, e isto enquanto princípio-jus; ou, ii) vislumbrá-la uma parte integrante de si, enquanto princípio-intentio de origem extrajurídica (moral, ética, religiosa, etc.); ou, por fim, iii) entendê-la parte integrante de si enquanto conteúdo de critério normativo positivado capaz de ser 
diretamente mobilizado no concreto juízo decisório.

Constituem estes os únicos modos de estruturação que essa relação pode comportar? Reitere-se, uma vez mais, a negativa. Tal como dissemos, para nós esses três modos não são os únicos existentes e/ou possíveis; constituem, na verdade, apenas três modos factíveis com a só diferença de que já foram objeto de alguma análise pela doutrina. Esta, portanto, e em nosso sentir, a relação entre a categoria tolerância e o mundo prático do direito.

\section{NOTAS}

E já, agora, um modo de ser-com-outros cada vez mais intensificado e densificado que só a conexão e vinculação proporcionada pelos processos de globalização em todos os seus aspectos (político, econômico, social, jurídico...) tornaria, neste grau, possível.

${ }^{2}$ Urgência que se prende, aliás, também com o fato de constituir a tolerância - no sentir de Castiglione e Mckinnon (2003b) - uma categoria vital para a moderna e globalizada sociedade democrática.

${ }^{3}$ Versão original: "Toleration, as a political principle, has enjoyed enormous success in the modern West" (FIALA, 2005, p. 01).

${ }^{4}$ Versão original: "toleration is one of the most important issues for the definition of a moral and political theory with application to modem globalized societies" (CASTIGLIONE; MCKINNON, 2003a).

${ }^{5}$ Versão original: "The concept of tolerance and its legitimate scope lies at the center of analysis" (ALMAGOR, 2006, p. 01).

${ }^{6}$ Preston King refere existir uma tal diferenciação também no âmbito da língua francesa (toleránce, tolération, tolérantisme) e italiana (tollerabilità, tollerànza, tollerazione) (KING, 1998).

${ }^{7}$ Há, inclusive, quem as negue, tal como faz Andrew Cohen (2004), e quem sequer as estabeleça, tal como o faz David Heyd (1996).

${ }^{8}$ Versão original: "precisely the act of being tolerant (or the disposition to be tolerant)" (NICHOLSON, 1986, p. 159). 
${ }^{9}$ Versão original: "is generally used as a term to describe a virtue, characteristic or tendency to engage in acts of toleration" (FIALA, 2005, p. 18).

${ }^{10}$ Originalmente publicada como: FORST, Rainer. Toleranz im Konflikt: Geschichte, Gehalt und Gegenwart Eines Umstrittenen Begriffs. Frankfurt Am Main: Suhrkamp Verlag, 2003.

${ }^{1}$ Para Preston King, este requisito da objeção tanto pode constituir um "dislike", no sentido de ser possível que a objeção represente apenas um não gostar, quanto pode constituir um "disapproval" a consubstanciar uma desaprovação. A objeção seria, então, um gênero do qual não gostar e desaprovar seriam espécies (KING, 1998).

${ }^{2}$ Versão original: "The reasons for objecting to particular practices may be of very different kinds and moral reasons represent just one possible category" (FORST, 2013, p. 19).

3 "A forma de atuar do sujeito tolerante não é em todo diferente a do prudente: em um primeiro momento conhece um ato alheio e delibera acerca do seu caráter extralimitado, em um segundo momento delibera sobre qual deve ser o proceder adequado - se a transigência ou a intransigência - e, finalmente, conclui com um mandato - de signo negativo - ordenando à vontade que se subtraia da réplica a que se teria direito" (tradução nossa) (RUIZ, 1985, p. 110).

${ }^{4}$ Para Forst (2013), aliás, a própria história da tolerância resume-se, de fato, à história das diversas concepções construídas para interpretar o conceito e as suas componentes, cada qual trazendo individualmente suas próprias justificações para o preenchimento destas três componentes normativas.

${ }^{5} \mathrm{O}$ trabalho de Ana Margarida Gaudêncio, sem desconsiderar os anteriores modos de relacionação possível, tem especial incidência neste terceiro, de quem, aliás, extraímos as lições. Para maiores aprofundamentos, cfr.: GAUDÊNCIO, Ana Margarida Simões. op. cit. pp. 511-613.

${ }^{6}$ Originalmente publicada como: KAUFMANN, Arthur. Rechtsphilosophie. München: Verlag, 1997.

${ }^{7}$ Para uma síntese concisa e mais detalhada da mundividência jurisprudencialista da qual partimos para encarar o direito, cfr.: NEVES, António Castanheira. O jurisprudencialismo: proposta de uma reconstituição 
crítica do sentido do direito. In: COELHO, Nuno M. M. Santos; SILVA, Antônio Sá da (Org.). Teoria do direito: direito interrogado hoje - o jurisprudencialismo: uma resposta possível? Estudos em homenagem ao Doutor António Castanheira Neves. Salvador: Juspodivm/Faculdade Baiana de Direito, 2012, pp. 9-79.

${ }^{8} \mathrm{E}$ isto porquanto as pretensões subjetivas de cada sujeito só podem emergir no âmbito de relações sociais, e no âmbito destas sempre na pressuposição de uma mediação pelo mundo (VALE, 2011).

9 "De outro modo: o valor é expressão de sentido da dialéctica do ser que o ser do homem institui. E daí o poder dizer-se - sem qualquer ilação historicista - que a sede da revelação do valor (dos valores) não a temos na ontologia, e sim na história: os valores revelam-se os sentidos fundamentantes com que o homem compreende e assume os projectos da sua realização histórica, e enquanto são antecipações de uma plenitude a que ele se abre no seu transcender" (NEVES, 2008, p. 19).

${ }^{20}$ Fernando Bronze (2002, p. 187) exemplifica elucidativamente esta ideia: "sempre que uma pessoa se dirige a outra afirmando 'paga-me $x$ porque me deves essa quantia', está a invocar um trans-individual que as vincula a ambas, pois é como se lhe afirmasse: 'paga-me $x$ porque o direito diz-nos (a ambos) que me deves essa quantia” (grifos postos). BRONZE, Fernando. BRONZE, Fernando José. Liçôes de introdução ao direito. Coimbra: Coimbra Editora, 2002, p. 187.

\title{
TOLERANCE AND LAW: POSSIBILITIES, PROJECTIONS AND LIMITS IN JURISPRUDENTIAL PERSPECTIVE
}

\begin{abstract}
The article aims to answer the question of what the meaning that the relationship between tolerance and law can or does have in the practical world of man. Our theoretical assumption is that, on the one hand, and since tolerance is a normatively dependent category, both the right may appear to it as only one normative resource among several possible, while, on the other hand, tolerance may turn out to be a normative resource, as principle or criterion, of law. To answer this question, we have divided the article into three sections. In the first, we identify, through two etymological approaches, the meanings that the tolerance category has assumed in the cultural world of Man. In the second, we seek to construct an analytical concept for our object and the necessary conditions for its practice. In the third section, we aim to verify how the relationship between law and tolerance is structured and what possible normative effects arise from this relation.
\end{abstract}


Keywords: Tolerance. Right. Principle. Criterion. Legal Tolerance.

\section{REFERÊNCIAS BIBLIOGRÁFICAS}

ALMAGOR, Raphael Cohen. The Scope of Tolerance. Studies on the costs of free expression and freedom of the press. New York: Routledge, 2006.

BRONZE, Fernando José. Lições de introdução ao direito. Coimbra: Coimbra Editora, 2002.

CASTIGLIONE, Dario; MCKINNON, Catrione. Introduction. In: CASTIGLIONE, Dario; MCKINNON, Catrione (eds.). Toleration, neutrality and democracy. Dordrecht: Springer, 2003a, pp. 1-7.

CASTIGLIONE, Dario; MCKINNON, Catrione. Introduction: reasonable tolerance. In: CASTIGLIONE, Dario; MCKINNON, Catrione (eds.). The culture of toleration in diverse societies. Manchester: Manchester University Press, 2003b, pp. 1-9.

COHEN, Andrew Jason. What toleration is. Ethics, vol. 115, n. 1, 2004, pp. 68-95.

FIALA, Andrew. Tolerance and ethical life. London: Continuum, 2005.

FORST, Rainer. Toleration, justice and reason. In: CASTIGLIONE, Dario; MCKINNON, Catrione (eds.). The culture of toleration in diverse societies. Manchester: Manchester University Press, 2003, pp. 71-85.

FORST, Rainer. Os limites da tolerância. Novos estud. - CEBRAP, n. 84, 2009, pp. 15-29. Disponível em: <http://www.scielo.br/scielo.php?script=sci_arttext\&pid=S0101-33002009000200002 >. Acesso em: 14 fev. 2016.

FORST, Rainer. Toleration in conflict. Past and present. Trasl. by Ciaran Cronin. New York: Cambridge University Press, 2013. 
FORST, Rainer. Toleration and democracy. Journal of Social Philosophy, vol. 45, n. 1, 2014, pp. 65-75.

GALEOTTI, Anna Elisabetta. Toleration as recognition. Cambridge: Cambridge University Press, 2004.

GAUDÊNCIO, Ana Margarida Simões. O intervalo da tolerância nas fronteiras da juridicidade - fundamentos e condições de possibilidade da projecção jurídica de uma (re)construção normativamente substancial da exigência de tolerância. Tese (Doutoramento em Direito) - Faculdade de Direito, Universidade de Coimbra, Coimbra 2012.

HART, Hebert. The concept of Law. Second Edition. Oxford: Clarendon Press, 1994.

HEYD, David (ed.). Toleration. An elusive concept. New Jersey: Princeton University Press, 1996.

KAUFMANN, Arthur. Filosofia do direito. 4a ed. Trad. de António Ulisses Cortês. Lisboa: Fundação Calouste Gulbekian, 2010 .

KING, Preston. Toleration. New edition. London: Frank Cass Publishers, 1998.

LINHARES, José Manuel Aroso. Introdução ao direito. Sumários desenvolvidos 2008-2009. Coimbra: Universidade de Coimbra, policopiado, 2008.

LINHARES, José Manuel Aroso. Na 'coroa de fumo' da teoria dos princípios: poderá um tratamento dos princípios como normas servir-nos de guia? In: CORREIA, Fernando Alves; MACHADO, Jónatas E. M.; LOUREIRO, João. Estudos em Homenagem ao Professor Doutor José Joaquim Gomes Canotilho. STVDIA IVRIDICA. 106. Ad Honorem - 6.Volume III - Direitos e interconstitucionalidade: entre dignidade e cosmopolitismo. Coimbra: Coimbra Editora, 2012, pp. 395-421.

NEVES, António Castanheira. Relatório: com a justificação do sentido e objectivo pedagógico, o programa, os conteúdos e os métodos de um curso de «Introdução ao estudo do direito». Coimbra: Universidade de Coimbra, policopiado, 1976.

NEVES, António Castanheira. Metodologia jurídica. Problemas fundamentais. Coimbra: Coimbra Editora, 1993. 
NEVES, António Castanheira. Teoria do Direito. Lições proferidas no ano lectivo de 1998/1999. Coimbra: Universidade de Coimbra, policopiado, 1998

NEVES, António Castanheira. Digesta. vol. I. Escritos acerca do direito, do pensamento jurídico, da sua metodologia e outros (reimpresso). Coimbra: Coimbra Editora, 2010.

NEVES, António Castanheira. Digesta. vol. II. Escritos acerca do direito, do pensamento jurídico, da sua metodologia e outros (reimpresso). Coimbra: Coimbra Editora, 2011

NEVES, António Castanheira. Digesta. vol. III. Escritos acerca do direito, do pensamento jurídico, da sua metodologia e outros. Coimbra: Coimbra Editora, 2008.

NEVES, António Castanheira. O jurisprudencialismo: proposta de uma reconstituição crítica do sentido do direito. In: COELHO, Nuno M. M. Santos; SILVA, Antônio Sá da (Org.). Teoria do direito: direito interrogado hoje - o jurisprudencialismo: uma resposta possível? Estudos em homenagem ao Doutor António Castanheira Neves. Salvador: Juspodivm/Faculdade Baiana de Direito, 2012, pp. 9-79.

NICHOLSON, Peter. Toleration as a moral Idea. In: HORTON, John; MENDUS, Susan (eds.). Aspects of toleration: philosophical studies. London: Routledge, 1985, pp. 158-173.

RAZ, Joseph. Freedom and autonomy. In: RAZ, Joseph. The morality of freedom. Oxford: 1986, pp. 400-429.

RUIZ, José Rámon Torres. El concepto de tolerancia. Revista de Estudios Politicos (Nueva Época), n. 48, pp. 105 134, 1985. Disponível em: <https://dialnet.unirioja.es/descarga/articulo/26870>. Acesso em: 02 mar. 2016.

REALE, Miguel. Filosofia do direito. 19a edição. São Paulo: Saraiva, 2002.

WALDRON, Jeremy. Toleration and reasonableness. In: CASTIGLIONE, Dario; MCKINNON, Catrione (eds.). The culture of toleration in diverse societies. Manchester: Manchester University Press, 2003, pp. 13-37.

VALDÉS, Ernesto Garzón. "No Pongas Tus Sucias Manos Sobre Mozart": Algunas consideraciones sobre el concepto de Tolerancia. Estudios filosofía-historia-letras, 1992. Disponível em: 
$<$ http://biblioteca.itam.mx/estudios/estudio/letras29/texto3/sec_1.html>.Acesso em: 14 mar. 2016.

VALE, Luís António Meneses Malheiros. Metodologia do direito. Guião das aulas práticas. Coimbra: Universidade de Coimbra, policopiado, 2011.

Trabalho enviado em 04 de junho de 2018

Aceito em 03 de setembro de 2018 